\title{
Effect of Vermicompost Amendment on Nutritional Status of Sandy Loam Soil, Growth Performance, and Yield of Pineapple (Ananas comosus var. MD2) under Field Conditions
}

\author{
Mawiyah Mahmud ${ }^{1}$, Rosazlin Abdullah ${ }^{1}$ and Jamilah Syafawati Yaacob ${ }^{1,2, *}$ \\ 1 Institute of Biological Sciences, Faculty of Science, University of Malaya, Kuala Lumpur 50603, Malaysia; \\ mawiyah@um.edu.my (M.M.); rosazlin@um.edu.my (R.A.) \\ 2 Centre for Research in Biotechnology for Agriculture (CEBAR), Institute of Biological Sciences, \\ Faculty of Science, University of Malaya, Kuala Lumpur 50603, Malaysia \\ * Correspondence: jamilahsyafawati@um.edu.my; Tel.: +60-3-7967-4090
}

Received: 17 July 2018; Accepted: 7 September 2018; Published: 12 September 2018

\begin{abstract}
Vermicompost is the product of composting or breaking down organic matter through the use of earthworms. It is rich in essential plant nutrients, and has the ability to enhance the condition and increase the quality of the soil. In the present study, a field trial was conducted from January 2015 until March 2016 to elucidate the effects of vermicompost application (compared to supplementation with chemical fertilizer and no fertilizer) on the sandy loam soil and plant nutrients of pineapple (Ananas comosus var. MD2). The morphophysiology and yield performance of MD2 pineapple grown with vermicompost in the field were also evaluated. In this study, vermicompost was applied onto the sandy loam soils during transplanting, followed by a second application at seven MAP (months after planting) at the rate of $10 \mathrm{tha}^{-1}$. On the other hand, the chemical fertilizer was applied based on the normal conventional cultivation practice. The soil and D-leaf samples at six MAP (S1) and during the red bud stage (S2; $10 \mathrm{MAP}$ ) were used to determine the soil and plant nutrient contents. The morphology of the plants was evaluated every month, and the fruits that were produced were subjected to quality analysis. Data analysis revealed that soil $\mathrm{pH}$ was increased after a second supplementation of vermicompost and contained significantly higher total $\mathrm{N}(0.15 \%)$ in the soils compared to the control $(0.07 \%)$. There was no significant difference between plants supplied with chemical fertilizer and vermicompost in terms of plant height, number of leaves, or the length and width of D-leaves. However, different fertilization treatments were found to affect the yield and physical characteristics of the resulting fruits. Plants supplied with chemical fertilizer produced the highest fruit yield (136.97 tha $\left.{ }^{-1}\right)$ with the largest fruit size, followed by vermicompost $\left(121.39 \mathrm{t} \mathrm{ha}^{-1}\right)$ and the control $\left(94.93 \mathrm{tha}^{-1}\right)$. However, fruits supplied with vermicompost were observed to have the smallest crowns. Taken together, these results indicated that the use of vermicompost produced pineapple plants with excellent growth performance, comparable to that obtained when chemical fertilizer was used. Also, based on the cost analysis conducted, it was shown that the total cost (fertilizer and labor) for plants grown with vermicompost was lower than plants grown with chemical fertilizer. However, the usage of vermicompost as the single source of nutrients is not suggested for this type of soil and field conditions, but can be used as a supplement to maintain the soil quality and ensure agricultural sustainability.
\end{abstract}

Keywords: vermicompost; organic agriculture; nutrients; growth productivity; pineapple; MD2; D-leaf length; SPAD reading; physicochemical properties 


\section{Introduction}

Agrochemicals have been widely used in the agronomic industry since its introduction in the 1960s during the 'Green Revolution', and have since been proven to boost food productivity [1]. However, the usage of these agrochemicals has been reported to produce harmful consequences to the environment and society [2]. Thus, efforts have been made by various scientific communities to look for alternative strategies to improve food production while ensuring environmental sustainability. Organic farming systems with the aid of various nutrients of biological origin such as compost or vermicompost are thought to be the answer for 'food safety and security' in the future [3].

Vermicompost is the excreta of earthworms, which are rich in humus, macronutrients, and micronutrients. It can improve soil health status, enhance crop production, and improve the physical properties of the soil [1,4]. Soil physical properties such as soil structure, texture, and tilth are the key factors that determine the agronomical potential of a land. These properties will largely influence the root penetrability, potential rooting volume, nutrient uptake and mobility, soil aeration, and water availability [5]. Soil texture is also key in affecting soil moisture content as well as the chemical properties of the soil, such as its cation exchange capacity (CEC) or the ability of the soil to hold positively charged ions [6]. For example, an area that contains a large proportion of sand is easier to be cultivated, but has poor moisture retention ability and low CEC, thus causing plant nutrients and water to leach out of the rooting zone very easily [5]. Therefore, the addition of composts such as vermicompost to the soil (particularly to sandy soil) is very beneficial, as they help increase the soil organic matter (SOM) composition, which in turn aids in improving soil aeration, maintaining good soil aggregation, protecting against soil erosion, and increasing nutrient availability [5,7]. Other than that, vermicompost also contains various plant nutrients such as $\mathrm{N}, \mathrm{P}, \mathrm{K}, \mathrm{Ca}, \mathrm{Mg}, \mathrm{S}, \mathrm{Fe}, \mathrm{Mn}, \mathrm{Zn}, \mathrm{Cu}$, and $\mathrm{B}$, which improve the nutrient content of different plant components such as the roots, shoots, and fruits [2]. Vermicompost can retain nutrients for a long time, and has a high water-holding capacity and high porosity compared to conventional compost due to its humus content [3]. At present, vermicompost has been widely used in the cultivation field, and its ability to produce good crop yields is well-known, as reported for maize [8], wheat [9], peppermint [10], and tomatoes [11]. The application of vermicompost yielded the same effect as in the case of inorganic fertilizers administration [12,13], therefore rendering vermicompost as a good alternative to replace the application of chemical fertilizer.

Pineapple (Ananas comosus var. MD2) is one of the tropical fruits that is highly demanded in the international market. This is due to its various quality characteristics whereby it was reported to have sweeter taste, blemish-free flesh, a cylinder shape with golden yellow pulp, a very pleasant aroma when ripe, low acidity, and a longer shelf life compared to other varieties [14,15]. However, a fruit's weight is directly dependent on plant vigor at the time of floral differentiation with a minimum D-leaf length of $1.0 \mathrm{~m}$ to gain fruits of more than $1.5 \mathrm{~kg}$ [16]. Therefore, fertilization plays an important role in crop management to increase the growth potential and crop yield. Pineapple plants have a large nutrient uptake demand, especially for potassium, followed by nitrogen, calcium, magnesium, sulfur, and phosphorus [16].

There have been many studies on the applications of various organic fertilizer onto pineapple plants, such as using composted poultry manure [17], composted pineapple residue return [18], and other composted materials [19-22]. According to Darnaudery, et al. [23], 'Queen Victoria' pineapple fruits produced via organic fertilization produced the highest total soluble solids content (TSS) and lowest titratable acidity (TA) compared to inorganic fertilization. However, there was no published report available on the supplementation of vermicompost to MD2 pineapple plants under field conditions. Thus, this study aimed to evaluate the morphophysiology and yield performance of MD2 pineapple grown with vermicompost in the field and its effect on the soil and plant nutrients. 


\section{Materials and Methods}

\subsection{Field Preparation}

In this project, a field study using a randomized complete block design (RCBD) with three treatment groups was conducted at Glami Lemi Biotechnology Research Centre (PPBGL), Jelebu, Malaysia ( $3^{\circ} 3^{\prime} \mathrm{N}$ latitude, $102^{\circ} 3^{\prime}$ E longitude) from January 2015 until March 2016 . The treatment groups included control plants, plants supplied with NPK fertilizer, and plants supplied with vermicompost. The experiment area was well-known as the warmest area in Malaysia with a mean monthly precipitation of $215 \mathrm{~mm}$, which mostly occurs from October to December, and less precipitation $(70 \mathrm{~mm})$ in January to February. The monthly average temperature ranges from $23^{\circ} \mathrm{C}$ (December-February) to $33^{\circ} \mathrm{C}$ (March-April).

The soil chemical properties of the field site are as described in Table 1 . The site was ploughed and furrowed to acquire a good tilth. Three raised beds were made and divided into four blocks, with each containing four beds. The individual plot size was $3 \mathrm{~m} \times 2 \mathrm{~m}$, and each was planted with 15 plants per plot. The beds and blocks were separated with a spacing of $1 \mathrm{~m}$ to ensure uninterrupted flow of irrigation for each individual plot. All of the beds were covered with silver shines (plastic mulch) with $0.03 \mathrm{~mm}$ of thickness. Plants were planted in double rows for each plot with plant-to-plant spacing of $60 \mathrm{~cm} \times 30 \mathrm{~cm}$.

Suckers (MD2) of 40-cm average height were obtained from Malaysian Pineapple Industrial Board (MPIB), Negeri Sembilan, Malaysia as the planting material. The nutrient availability in vermicompost was total N 1.54\%, total phosphorus (P) 0.64\%, total potassium (K) 6.31\%, total magnesium (Mg) $0.58 \%$, total calcium (Ca) $1.39 \% \mathrm{Ca}$, total sulfur (S) $0.34 \%$, total zinc ( $\mathrm{Zn}$ ) $0.01 \%$, total boron (B) $0 \%$, total iron (Fe) $0.76 \%$, and total aluminum (Al) $1.04 \%$. The vermicompost was incorporated into the top $10 \mathrm{~cm}$ of the soil at the recommended rate $\left(10 \mathrm{t} \mathrm{ha}^{-1}\right)$ twice along planting, during transplanting and at seven months after planting (MAP) (one month before flowering was induced).

Table 1. Chemical properties and texture of soil in the study site prior to cropping.

\begin{tabular}{cc}
\hline Parameters & Values \\
\hline Soil $\mathrm{pH}$ & 5.65 \\
Electrical Conductivity, EC $(\%)$ & 57.90 \\
Total N $(\%)$ & 0.06 \\
Total C $(\%)$ & 0.51 \\
Available P $(\mathrm{ppm})$ & 92.28 \\
Exchangeable K (cmol/ $\mathrm{kg})$ & 0.21 \\
Exchangeable Ca $(\mathrm{cmol} / \mathrm{kg})$ & 0.85 \\
Exchangeable $\mathrm{Mg}(\mathrm{cmol} / \mathrm{kg})$ & 0.18 \\
Texture & Sandy Loam \\
\hline
\end{tabular}

Chemical fertilizer was applied to the soil based on the rate recommended by the Malaysian Pineapple Industry Board [24], with minor modifications. NPK (15:15:15) fertilizer granules were applied at the rate of $20 \mathrm{~g}$ per plant at one month, three months, and seven months after planting (MAP). A foliar fertilizer mix was sprayed twice at 1.5 months ( $640 \mathrm{~g}$ of hydrated lime, $42 \mathrm{~g}$ of copper sulfate, $42 \mathrm{~g}$ of zinc sulfate, $21 \mathrm{~g}$ of ferrous sulfate in $18 \mathrm{~L}$ of water) and 4.5 months (added 640-gm urea in $18 \mathrm{~L}$ of water, as before) after planting. Fifty to 100 milliliters (50-100 mL) of fertilizer was sprayed onto the leaves of each plant. Then, $50 \mathrm{~mL}$ of Ethrel (2-chloroethyl phosphonic acid) solution (15 $\mathrm{mL}$ of Ethrel and $90 \mathrm{~g}$ of urea in $9 \mathrm{~L}$ of water) was sprayed at the center of the pineapple plants at nine months after planting (MAP) to induce flowering. The plants were watered when necessary using a sprinkler water system, while weeds on the plots were manually controlled (through pulling and cutting) intermittently. 


\subsection{Soil and Plant Chemical Analysis}

Before sampling, three core soil samples were randomly collected from 0 to $15 \mathrm{~cm}$ of topsoil by using a Dutch Auger and bulk to form a composite $[25,26]$. Samples were air-dried, crushed using a mortar and pestle, and allowed to pass through a 2.0-mm sieve for soil $\mathrm{pH}$ analysis, and then $0.25-\mathrm{mm}$ sieves for total elements analysis. The nutrients in the plants were determined using the D-leaves as the samples. The D-leaves were identified by gathering all of the leaves in the hands to form a vertical "bundle" in the center of the plant where the D-leaves are the longest ones [27]. Twelve samples per treatment were collected at random and washed with distilled water, then blot-dried before being dried in an oven at $60 \pm 5{ }^{\circ} \mathrm{C}$. The dried D-leaf samples were finely ground and kept in airtight containers until further analysis. The sampling of both soil and D-leaves were conducted on the same day at six months after planting (S1; 6 MAP) and during the red bud stage (S2; 10 MAP).

The soil $\mathrm{pH}$ was measured at a soil/distilled water ratio of 1:2.5 [28]. The mixture was shaken using an orbital shaker (ZP-200, Meditry Instrument, China) for $1 \mathrm{~h}$ at $2.5 \times 100 \mathrm{rpm}$, and then the $\mathrm{pH}$ was determined using a pH electrode (PB-10, Sartorius, Germany). The total nitrogen (N) of the D-leaf samples was determined via dry combustion using a Nitrogen Determinator (FP-528, LECO, UK) [29], while the total nitrogen $(\mathrm{N})$ in the soil was determined by the Kjeldahl method [30]. The content of other total elements, Phosphorus (P), Potassium (K), Sulfur (S), Calcium (Ca), Magnesium (Mg), Zinc (Zn), Iron $(\mathrm{Fe})$, Boron $(\mathrm{B})$, and Aluminum $(\mathrm{Al})$ were determined by the aqua regia digestion method [31]. The filtrated solution was analyzed by using an inductive couple plasma optical emission spectrometer (725-ES ICP-OES, Varian, Australia). On the other hand, elements in the D-leaves were determined by dry ashing method [32,33]. A blank digest was carried out in the same way, as the control.

\subsection{Morphophysiology of Pineapple Plants}

Twelve plants from each treatment were tagged for data collection. For vegetative data collection, the number of leaves, plant height, and length and width of the D-leaf were measured every month, starting from $2 \mathrm{MAP}$, until the fruits were harvested. The height of the plants was measured with a meter ruler, and the number of leaves was determined by manual counting. The length and width of the D-leaves were also measured with a meter ruler from three leaves per plant. The chlorophyll content was measured with a Minolta chlorophyll meter (SPAD-502, Konica Minolta, Tokyo, Japan) every two months by averaging the SPAD readings from the basal, middle, and tip of the D-leaves [34]. The SPAD readings were taken before 09:00 or after 17:30 under the shade.

\subsection{Physical Characteristics of Fruit Analysis}

For the physical properties of the fruits, fruit weight, fruit weight without the crown, the diameter of the fruit, and the weight and length of the crown were determined. The weight of fruits with the crown, without the crown, and crown weight was determined using a digital balance (EK-6000i, $A \& D$, Tokyo, Japan). The length of the fruit and the crown was measured with a meter ruler, and the diameter of fruit was measured using digital calipers. The pineapple fruit was cut into two parts. At the bottom, middle, and top of the fruits, the pulp firmness was measured using a fruit hardness tester (Nippon Optical Works, Tokyo, Japan) and defined as in the kilogram force (kg f) required to penetrate the tissue. The core diameter was measured using a ruler at three different places: the bottom, middle, and top of the fruits.

\subsection{Total Soluble Solids (TSS)}

The total soluble solids were measured using a digital refractometer (PR-1, Atago, Tokyo, Japan). First, $30 \mathrm{~g}$ of the pulp tissue was blended in $90 \mathrm{~mL}$ of distilled water using a laboratory blender for two min, and then it was filtered. A single drop of the filtrate was placed on the prism of the refractometer. The recorded value was multiplied by three, since the initial pulp sample was diluted three times with distilled water [35]. The refractometer was standardized with distilled water. 


\subsection{Total Titratable Acidity (TTA)}

Thirty grams ( $30 \mathrm{~g}$ ) of the pulp was weighed and transferred into a blender with $90 \mathrm{~mL}$ of distilled water; then, it was blended for two minutes and filtered. Then, $25 \mathrm{~mL}$ of the filtrate was transferred into a 125-mL conical flask. Another $25 \mathrm{~mL}$ of distilled water and four to five drops of phenolphthalein indicator was added. The solution was titrated against $0.1 \mathrm{~N}$ of sodium hydroxide $(\mathrm{NaOH})$ until there was a sharp color change from light yellow to pink. The titre volume of $\mathrm{NaOH}$ added was recorded and multiplied by the citric acid factor (0.07) to obtain the total titratable acidity [35]. The sugar-to-acid ratio of the samples was also calculated by determining the ratio of TSS/TTA.

\subsection{Cost Estimation}

The cost of labor and fertilizer used throughout the study was also analyzed. Total profit (per $\mathrm{kg}$ fruit and per plant per year) was then estimated by calculating the difference between the total value of the fruits produced (in Ringgit Malaysia; RM) and the total cost. In this study, the cost of labor was fixed at RM50/day per person, while the market price of the fruits was fixed at RM8 per kg [36]. The cost of the starting material (seedling), irrigation, and flower-inducing hormone were not included in the cost analysis.

\subsection{Data Analysis}

Results are expressed as mean \pm standard error of mean. Soil and plant nutrient contents and fruits attributes data were analyzed by one-way analysis of variance (ANOVA). Data of the growth performance of plants (plant height, number of leaves, length and width of D-leaves, and SPAD reading of D-leaves) were analyzed by repeated measures ANOVA (rANOVA). The differences between treatment means were separated using Duncan's multiple range test (DMRT) at 5\% significance level. Correlations among all of the data were calculated using Pearson's correlation coefficient in bivariate correlations. All of the statistical analysis was done by using SPSS software version 24 .

\section{Results}

\subsection{Soil and Plant Nutrients Analysis}

Based on Table 2, it was observed that the soil $\mathrm{pH}$ at six MAP (S1; during the vegetative stage of the pineapple plants) was maintained within the range of the recommended $\mathrm{pH}$, which is between 4.5-6.5 [22]. However, at the red bud stage (S2), the soil $\mathrm{pH}$ had greatly reduced when supplemented with chemical fertilizer to be much lower than the recommended range of soil $\mathrm{pH}$ for pineapple plants ( $\mathrm{pH} 4.30)$. In contrast, a significant increase in soil $\mathrm{pH}$ (5.77) was obtained after a second application of vermicompost to the plants, whereby the $\mathrm{pH}$ was slightly higher than the control (S1 and S2).

Table 2. Soil $\mathrm{pH}$ at six months of planting (S1) and during red bud stage (S2).

\begin{tabular}{cccc}
\hline Time of Sampling & Control & Chemical Fertilizer & Vermicompost \\
\hline S1 & $5.44 \pm 0.21^{\mathrm{a}}$ & $4.79 \pm 0.09^{\mathrm{b}}$ & $4.99 \pm 0.17^{\mathrm{ab}}$ \\
S2 & $5.45 \pm 0.15^{\mathrm{a}}$ & $4.30 \pm 0.11^{\mathrm{b}}$ & $5.77 \pm 0.13^{\mathrm{a}}$ \\
\hline
\end{tabular}

Note: Mean \pm standard error within each row followed by a different letter indicates significant differences at $p \leq 0.05$ according to Duncan's multiple range test (DMRT).

Data on the soil nutrients content (N, P, K, Mg, S, Ca, Fe, Zn, B, and Al) taken at six months after planting (S1) and during the red bud stage (S2) from plots grown with MD2 pineapple plants are presented in Table 3. Total $\mathrm{N}$ in the soils supplemented with vermicompost $(0.10 \%$ at $\mathrm{S} 1$ and $0.15 \%$ at S2) was higher than in soils supplied with chemical fertilizer $(0.09 \%$ at both S1 and S2). The N concentration was observed to increase from $\mathrm{S} 1$ to $\mathrm{S} 2$, when the soils were supplied with vermicompost twice along the cycle. However, no increase in $\mathrm{N}$ concentration was observed when chemical fertilizer 
was supplied periodically. Therefore, in contrast to the application of vermicompost, the chemical fertilizer has to be continuously supplied to the soil to increase the nutrients concentration required for plant growth.

Table 3. Concentration of soil nutrients six months after planting (S1) and on the emergence of inflorescence (S2) grown with MD2 pineapple plants.

\begin{tabular}{ccccccc}
\hline \multirow{2}{*}{$\begin{array}{c}\text { Total } \\
\text { Elements }\end{array}$} & \multicolumn{2}{c}{ Control } & \multicolumn{2}{c}{ Chemical Fertilizer } & \multicolumn{2}{c}{ Vermicompost } \\
\cline { 2 - 7 } & S1 & S2 & S1 & S2 & S1 & S2 \\
\hline $\mathrm{N} \mathrm{( \% )}$ & $0.03 \pm 0.02^{\mathrm{c}}$ & $0.07 \pm 0.02^{\mathrm{bc}}$ & $0.09 \pm 0.02^{\mathrm{abc}}$ & $0.09 \pm 0.02^{\mathrm{abc}}$ & $0.10 \pm 0.02^{\mathrm{ab}}$ & $0.15 \pm 0.01^{\mathrm{a}}$ \\
$\mathrm{P}(\%)$ & $0.02 \pm 0.00^{\mathrm{a}}$ & $0.02 \pm 0.00^{\mathrm{a}}$ & $0.04 \pm 0.02^{\mathrm{a}}$ & $0.04 \pm 0.01^{\mathrm{a}}$ & $0.03 \pm 0.01^{\mathrm{a}}$ & $0.04 \pm 0.00^{\mathrm{a}}$ \\
$\mathrm{K}(\%)$ & $0.08 \pm 0.02^{\mathrm{ab}}$ & $0.05 \pm 0.00^{\mathrm{b}}$ & $0.10 \pm 0.02^{\mathrm{a}}$ & $0.07 \pm 0.01^{\mathrm{ab}}$ & $0.09 \pm 0.01^{\mathrm{ab}}$ & $0.07 \pm 0.01^{\mathrm{ab}}$ \\
$\mathrm{Mg}(\%)$ & $0.04 \pm 0.00^{\mathrm{a}}$ & $0.04 \pm 0.00^{\mathrm{a}}$ & $0.05 \pm 0.01^{\mathrm{a}}$ & $0.05 \pm 0.01^{\mathrm{a}}$ & $0.05 \pm 0.01^{\mathrm{a}}$ & $0.06 \pm 0.01^{\mathrm{a}}$ \\
$\mathrm{S}(\%)$ & $0.01 \pm 0.00^{\mathrm{a}}$ & $0.01 \pm 0.00^{\mathrm{a}}$ & $0.02 \pm 0.01^{\mathrm{a}}$ & $0.02 \pm 0.00^{\mathrm{a}}$ & $0.02 \pm 0.01^{\mathrm{a}}$ & $0.02 \pm 0.00^{\mathrm{a}}$ \\
$\mathrm{Ca} \mathrm{( \% )}$ & $0.06 \pm 0.01^{\mathrm{ab}}$ & $0.06 \pm 0.01^{\mathrm{ab}}$ & $0.09 \pm 0.02^{\mathrm{a}}$ & $0.04 \pm 0.01^{\mathrm{b}}$ & $0.08 \pm 0.01^{\mathrm{a}}$ & $0.08 \pm 0.01^{\mathrm{ab}}$ \\
$\mathrm{Fe} \mathrm{( \% )}$ & $0.64 \pm 0.05^{\mathrm{a}}$ & $0.68 \pm 0.04^{\mathrm{a}}$ & $0.71 \pm 0.06^{\mathrm{a}}$ & $0.80 \pm 0.13^{\mathrm{a}}$ & $0.73 \pm 0.09^{\mathrm{a}}$ & $0.80 \pm 0.10^{\mathrm{a}}$ \\
$\left.\mathrm{Zn} \mathrm{(mg} \mathrm{kg}{ }^{-1}\right)$ & $34.76 \pm 3.12^{\mathrm{a}}$ & $35.81 \pm 8.49^{\mathrm{a}}$ & $38.26 \pm 1.99^{\mathrm{a}}$ & $33.20 \pm 5.00^{\mathrm{a}}$ & $40.05 \pm 4.31^{\mathrm{a}}$ & $37.63 \pm 2.94^{\mathrm{a}}$ \\
$\left.\mathrm{B} \mathrm{(mg} \mathrm{kg}{ }^{-1}\right)$ & $2.81 \pm 0.86^{\mathrm{a}}$ & $2.22 \pm 0.73^{\mathrm{a}}$ & $3.02 \pm 0.75^{\mathrm{a}}$ & $2.17 \pm 0.70^{\mathrm{a}}$ & $2.10 \pm 1.16^{\mathrm{a}}$ & $2.56 \pm 1.61^{\mathrm{a}}$ \\
$\mathrm{Al} \mathrm{( \% )}$ & $2.74 \pm 2.09^{\mathrm{a}}$ & $2.85 \pm 0.29^{\mathrm{a}}$ & $3.46 \pm 0.53^{\mathrm{a}}$ & $4.13 \pm 0.88^{\mathrm{a}}$ & $3.11 \pm 0.36^{\mathrm{a}}$ & $3.48 \pm 0.70^{\mathrm{a}}$ \\
\hline
\end{tabular}

Note: Mean \pm standard error within each row followed by a different letter indicates significant differences at $p \leq 0.05$ according to Duncan's multiple range test (DMRT).

On the other hand, Table 4 shows the macronutrients content in the D-leaves of MD2 pineapple plants. Data analysis showed that the mean of total N ranged from $0.69 \%$ to $1.44 \%$ in the D-leaves. At the red bud stage (S2), all of the treatments showed a reduction of $\mathrm{N}$ content in the leaf samples; however, these values were still adequate for the growth of pineapple plants $(\mathrm{N}>0.66 \%)$ [37]. Based on Pearson's correlation analysis, a strong significant correlation was observed between $\mathrm{N}$ content in the soil and in the plants, when supplied with chemical fertilizer $\left(p<0.05, \mathrm{r}^{2}=-0.970\right)$, indicating sufficient $\mathrm{N}$ uptake from the soils. Although higher $\mathrm{N}$ content was observed in the soil supplied with vermicompost, the correlation between the $\mathrm{N}$ content in the soil and plants was weak $\left(\mathrm{r}^{2}=0.236\right)$. In this study, Ca concentrations in the soil supplied with chemical fertilizer at $\mathrm{S} 2$ showed the lowest concentration compared to other treatments, with only $0.04 \% \mathrm{Ca}$. The low availability of $\mathrm{Ca}$ in the soils has also affected the Ca uptake by the pineapple plants (Table 4).

Table 4. Concentration of macronutrients (\%) in the D-leaf of MD2 pineapple plants six months after planting (S1) and during the red bud stage (S2) $(n=4)$.

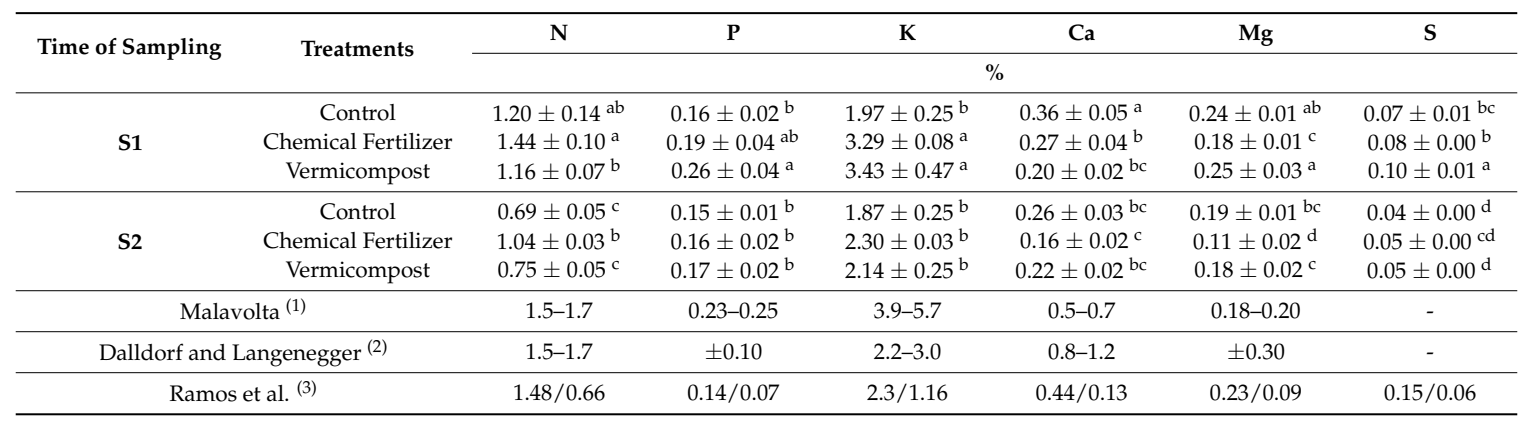

Note: Means \pm standard error followed by a different letter in a column indicates significant differences according to Duncan's multiple range test (DMRT) at $p \leq 0.05$. (1) Ideal concentration at four months (whole leaf), source: Souza \& Reinhardt [16]. (2) Ideal concentrations at the inflorescence emergence (whole leaf), source: Malezieux \& Bartholomew, Souza \& Reinhardt $[15,16] .{ }^{(3)}$ Ideal concentrations/deficiency concentration at floral induction [37].

The Fe, $\mathrm{Zn}, \mathrm{B}$, and $\mathrm{Al}$ content in the MD2 pineapple D-leaves are detailed in Table 5. The Fe levels in the leaves ranged from $46.93 \mathrm{mg} \mathrm{kg}^{-1}$ to $73.32 \mathrm{mg} \mathrm{kg}^{-1}$, which was below the recommended range (100-200 mg kg ${ }^{-1}$ ) for crop growth [15]. The Zn content was twofold above the level that is considered ideal for the growth of pineapple plants, with $\mathrm{Zn}$ content ranging from $21.00 \mathrm{mg} \mathrm{kg}^{-1}$ to $29.76 \mathrm{mg} \mathrm{kg}^{-1}$ 
at S2. In addition, the application of vermicompost onto the soils also increased the B content in MD2 pineapple D-leaves at S1 (11.36 $\left.\mathrm{mg} \mathrm{kg}^{-1}\right)$. At S2, the plants treated with vermicompost had low B content, although it was still above the level that was considered insufficient to support plant growth. This is in direct contrast to the plants supplemented with chemical fertilizer and control (unfertilized) plants, where the B content during S2 was found to be too low, and thus was not sufficient for plant growth.

Table 5. Concentration of micronutrients in the D-leaf of MD2 pineapple plants on six months after planting (S1) and during the red bud stage (S2).

\begin{tabular}{|c|c|c|c|c|c|}
\hline \multirow{2}{*}{ Time of Sampling } & \multirow{2}{*}{ Treatments } & $\mathrm{Fe}$ & $\mathrm{Zn}$ & B & Al \\
\hline & & \multicolumn{4}{|c|}{$\mathrm{mg} \mathrm{kg}^{-1}$} \\
\hline \multirow{3}{*}{ S1 } & Control & $61.93 \pm 6.18^{a}$ & $39.82 \pm 5.50^{\mathrm{a}}$ & $5.58 \pm 0.89 \mathrm{bc}$ & $57.61 \pm 11.34^{\mathrm{a}}$ \\
\hline & Chemical Fertilizer & $64.84 \pm 16.54^{\mathrm{a}}$ & $44.14 \pm 5.04^{\mathrm{a}}$ & $5.68 \pm 0.55^{b c}$ & $4447 \pm 9.96^{\mathrm{a}}$ \\
\hline & Vermicompost & $73.32 \pm 20.35^{a}$ & $41.63 \pm 9.83^{a}$ & $11.36 \pm 1.82^{\mathrm{a}}$ & $48.41 \pm 11.99^{\mathrm{a}}$ \\
\hline \multirow{3}{*}{ S2 } & Control & $65.26 \pm 1497^{a}$ & $29.76 \pm 3.30^{a b}$ & $4.33 \pm 0.47 \mathrm{bc}$ & $19.43 \pm 1.13^{b}$ \\
\hline & Chemical Fertilizer & $46.93 \pm 9.49^{\mathrm{a}}$ & $21.00 \pm 1.63^{b}$ & $2.98 \pm 0.15^{c}$ & $10.59 \pm 1.29^{b}$ \\
\hline & Vermicompost & $68.69 \pm 17.60^{\mathrm{a}}$ & $22.13 \pm 1.51^{\mathrm{b}}$ & $6.33 \pm 0.83^{b}$ & $11.73 \pm 3.19^{b}$ \\
\hline \multicolumn{2}{|c|}{ Malavolta (1) } & $600-1000$ & $17-39$ & - & - \\
\hline \multicolumn{2}{|c|}{ Dalldorf and Langenegger (2) } & $100-200$ & \pm 10 & 30 & - \\
\hline \multicolumn{2}{|c|}{ Ramos et al. (2009) (3) } & - & - & $20 / 5.6$ & - \\
\hline
\end{tabular}

Note: Means \pm standard error followed by a different letter in a column indicates significant differences according to Duncan's multiple range test (DMRT) at $p<0.05$. ${ }^{(1)}$ Ideal concentration at four months (whole leaf), source: Souza \& Reinhardt [16] ${ }^{(2)}$ Ideal concentrations at the inflorescence emergence (whole leaf), source: Malezieux \& Bartholomew, Souza \& Reinhardt $[15,16] .{ }^{(3)}$ Ideal concentrations/deficiency concentration at floral induction [37].

\subsection{Morphophysiology Analysis}

Figure 1a shows the height of MD2 pineapple plants measured from two MAP until 13 MAP increased from $41.2 \mathrm{~cm}$ to $106.5 \mathrm{~cm}$. Data analysis revealed that MD2 pineapple plants supplemented with chemical fertilizer grew taller than plants supplemented with vermicompost and control plants, with mean plant heights of $83.0 \mathrm{~cm}, 79.6 \mathrm{~cm}$, and $76.3 \mathrm{~cm}$, respectively. However, the difference in the height of plants supplemented with chemical fertilizer and vermicompost was not statistically significant (Table 6). Furthermore, a similar trend was observed on the number of leaves of the pineapple plants (Figure 1b). After flowering (10 MAP), the number of leaves remained unchanged with time (Figure 1c). Moreover, the length of the D-leaves possessed by plants supplemented with chemical fertilizer and vermicompost was also not statistically significantly different at $p \leq 0.05$ (Table 6). 


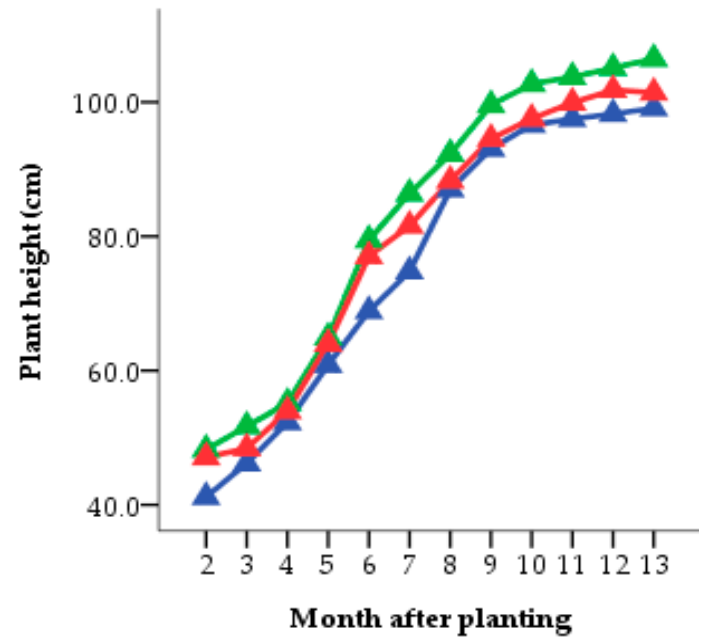

(a)

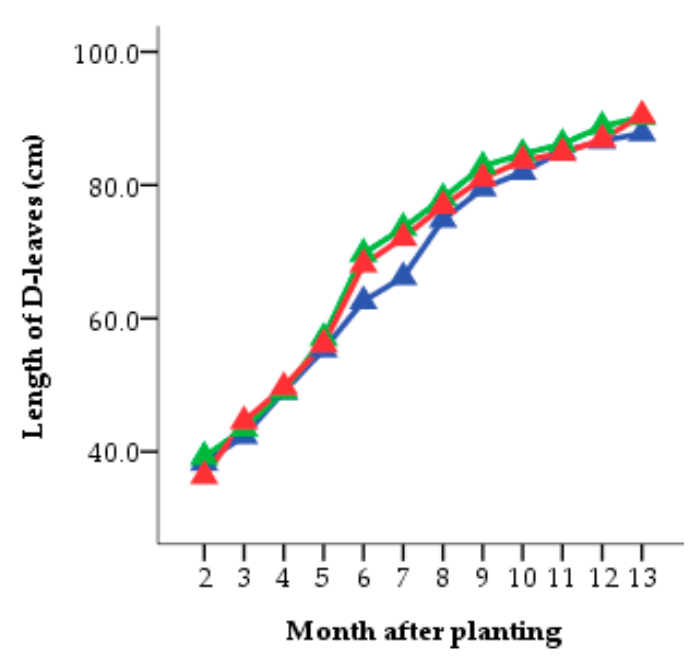

(c)

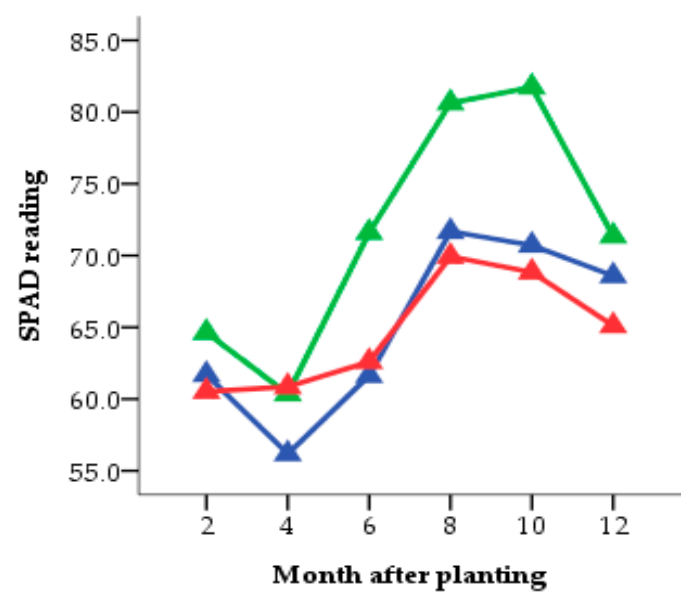

(e)

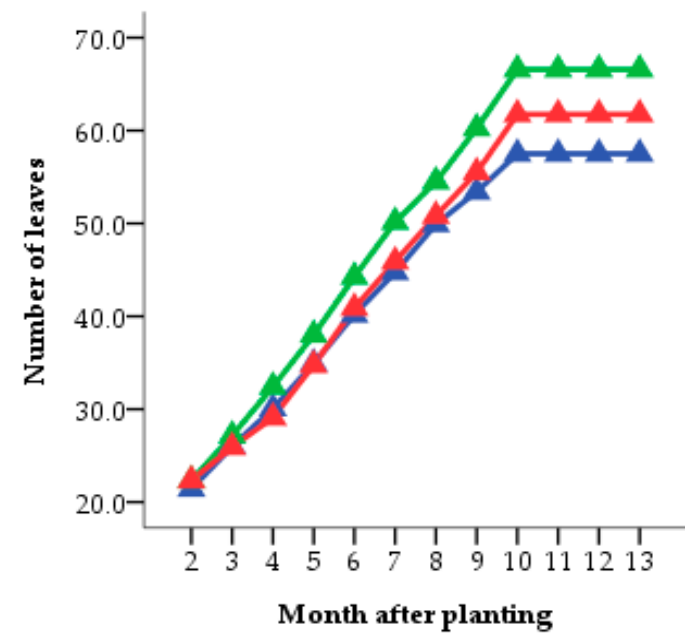

(b)

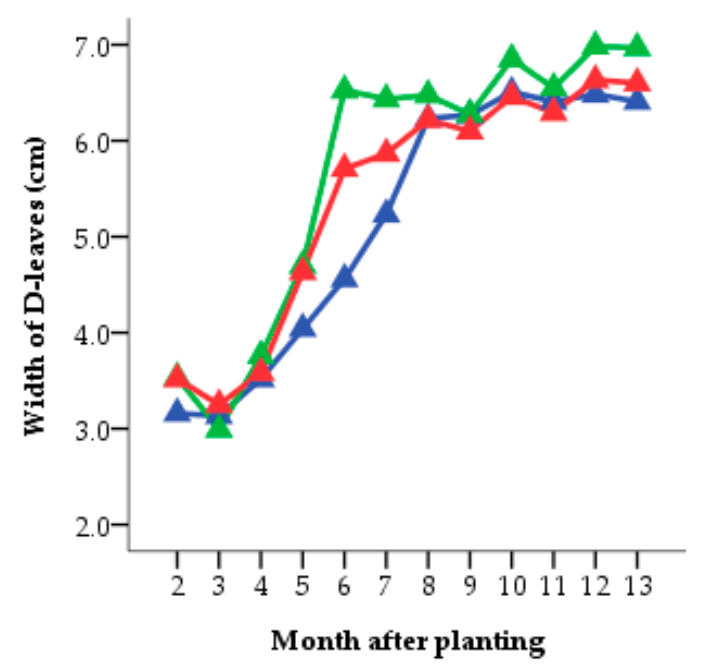

(d)

Figure 1. Effect of supplementation of vermicompost and chemical fertilizer on (a) the height of the plant, (b) number of leaves, (c) length of D-leaves, (d) width of D-leaves, and (e) SPAD reading of D-leaves of MD2 pineapple plants in the field from two months after planting until harvesting. 
Table 6. Morphophysiology of MD2 pineapple plants grown with different types of fertilizers.

\begin{tabular}{cccc}
\hline Morphology & Control & Chemical Fertilizer & Vermicompost \\
\hline Plant height $(\mathrm{cm})$ & $76.3 \pm 1.3^{\mathrm{b}}$ & $82.98 \pm 1.3^{\mathrm{a}}$ & $79.6 \pm 1.3^{\mathrm{ab}}$ \\
Number of leaves & $42 \pm 1^{\mathrm{b}}$ & $47 \pm 1^{\mathrm{a}}$ & $44 \pm 1^{\mathrm{ab}}$ \\
Length of D-leaves $(\mathrm{cm})$ & $67.5 \pm 1.3^{\mathrm{a}}$ & $70.2 \pm 1.3^{\mathrm{a}}$ & $69.2 \pm 1.3^{\mathrm{a}}$ \\
Width of D-leaves $(\mathrm{cm})$ & $5.2 \pm 0.1^{\mathrm{b}}$ & $5.7 \pm 0.1^{\mathrm{a}}$ & $5.4 \pm 0.1^{\mathrm{ab}}$ \\
SPAD readings & $65.1 \pm 0.9^{\mathrm{b}}$ & $71.7 \pm 0.9^{\mathrm{a}}$ & $64.6 \pm 0.9^{\mathrm{b}}$ \\
\hline
\end{tabular}

Note: Mean \pm standard error of mean analyzed by repeated measures ANOVA. The different letter within each row indicates significant differences at $p \leq 0.05$ according to Duncan's multiple range test (DMRT).

Based on Figure 1d, there was no significant difference between the width of the D-leaves from plants supplemented with chemical fertilizer and vermicompost from two MAP until 13 MAP. However, at six MAP, plants supplemented with chemical fertilizer showed significantly wider D-leaves compared to control plants, with D-leaf widths of $6.5 \mathrm{~cm}$ and $4.6 \mathrm{~cm}$, respectively. The width of the D-leaves nearly plateaued after flowering was induced, resulting in the maximum width of $7.0 \mathrm{~cm}$. Therefore, taking together all of the results of the following data analysis, it was evident that the growth performance (in terms of plant height, number of leaves, and length and width of D-leaves) of pineapple plants supplied with vermicompost was comparable to the plants supplemented with chemical fertilizer.

Moreover, as depicted in Figure 1e, the SPAD readings ranged from 56.19 SPAD to 81.73 SPAD from two MAP until 12 MAP. The SPAD readings drastically increased in plants supplemented with chemical fertilizer from six months after planting (Figure 1e), whereby the plants were already at their maturation stage. During flowering, the range of SPAD readings of the pineapple leaves from all of the treatments was comparable (65.11 SPAD to 68.58 SPAD). Nevertheless, the SPAD reading of pineapple leaves supplied with chemical fertilizer was observed to be greatly reduced after 12 MAP.

\subsection{Physical Characteristics of Fruits}

Based on Table 7, pineapple plants supplied with chemical fertilizer were shown to produce the highest fruit yield, with $136.97 \mathrm{tha}^{-1}$ of pineapple fruits, while plants supplied with vermicompost and control plants produced $121.39 \mathrm{t} \mathrm{ha}^{-1}$ and $94.93 \mathrm{t} \mathrm{ha}^{-1}$ respectively. Overall, pineapple plants supplied with chemical fertilizer produced the largest fruit size, followed by plants supplied with vermicompost and control.

Table 7. Physical characteristics of MD2 pineapple fruits grown with different types of fertilizers.

\begin{tabular}{cccc}
\hline Analysis & Control & Chemical Fertilizer & Vermicompost \\
\hline Estimated yield $\left(\mathrm{t} \mathrm{ha}^{-1}\right)$ & $94.93 \pm 6.31^{\mathrm{c}}$ & $136.97 \pm 0.89^{\mathrm{a}}$ & $121.39 \pm 4.71^{\mathrm{b}}$ \\
Fruit weight $(\mathrm{g})$ & $1709 \pm 114^{\mathrm{c}}$ & $2466 \pm 16^{\mathrm{a}}$ & $2185 \pm 255^{\mathrm{b}}$ \\
Fruit weight without crown $(\mathrm{g})$ & $1421 \pm 103^{\mathrm{c}}$ & $2236 \pm 23^{\mathrm{a}}$ & $1953 \pm 68^{\mathrm{b}}$ \\
Fruit diameter $(\mathrm{cm})$ & $10.90 \pm 0.2^{\mathrm{b}}$ & $11.90 \pm 0.3^{\mathrm{a}}$ & $11.60 \pm 0.2^{\mathrm{a}}$ \\
Fruit length $(\mathrm{cm})$ & $16.90 \pm 0.0^{\mathrm{c}}$ & $24.50 \pm 0.4^{\mathrm{a}}$ & $20.30 \pm 0.8^{\mathrm{b}}$ \\
Crown weight $(\mathrm{g})$ & $330 \pm 10^{\mathrm{a}}$ & $247 \pm 29^{\mathrm{b}}$ & $232 \pm 86^{\mathrm{b}}$ \\
Crown length $(\mathrm{cm})$ & $22.40 \pm 0.8^{\mathrm{a}}$ & $18.50 \pm 1.4^{\mathrm{b}}$ & $16.70 \pm 1.4^{\mathrm{b}}$ \\
Core diameter $(\mathrm{cm})$ & $2.20 \pm 0.0^{\mathrm{b}}$ & $2.60 \pm 0.3^{\mathrm{a}}$ & $2.40 \pm 0.4^{\mathrm{ab}}$ \\
Pulp firmness $(\mathrm{kg} \mathrm{f})$ & $0.77 \pm 0.004^{\mathrm{a}}$ & $0.67 \pm 0.017^{\mathrm{b}}$ & $0.74 \pm 0.007^{\mathrm{a}}$ \\
\hline
\end{tabular}

Note: Mean \pm standard error of mean within each row followed by a different letter indicates significant differences at $p \leq 0.05$ according to Duncan's multiple range test (DMRT).

Figure 2 illustrates the different sizes of MD2 pineapple fruits harvested from plants treated with different types of fertilizer. Based on the weight of the resulting fruits, the fruits can be graded to A grade ( $>1.7 \mathrm{~kg}), B$ grade (1.3 to $1.6 \mathrm{~kg})$, and C grade $(<1.3 \mathrm{~kg})$ [38]. In this experiment, based on the fruit weight without the crown, it was observed that both treatments with vermicompost and chemical 
fertilizer produced grade-A fruits, while control plants produced only grade-B fruits. Moreover, data analysis also showed that the weight and length of the crown was significantly smallest when plants were supplied with vermicompost or chemical fertilizer, compared to control (unfertilized) plants. However, the fruit's core size showed that fruits harvested from plants treated with chemical fertilizer were significantly wider compared to the control. A similar trend was observed for pulp firmness, where the fruits produced from plants supplied with chemical fertilizer had less pulp firmness $(0.67 \mathrm{~kg} \mathrm{f})$ than the fruits produced from plants supplied with vermicompost $(0.74 \mathrm{~kg} \mathrm{f})$ and control plants $(0.77 \mathrm{~kg}$ f).

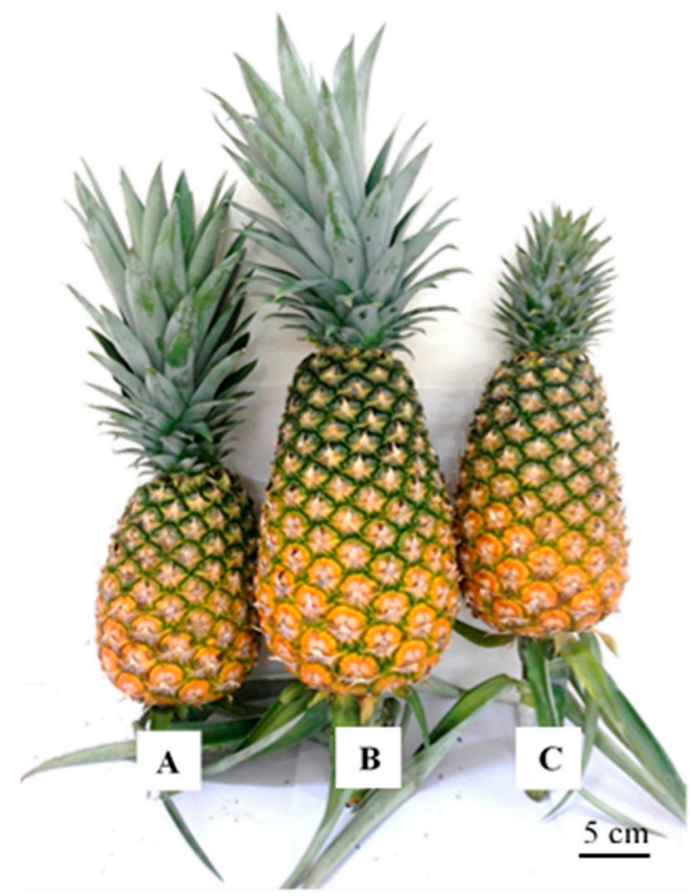

Figure 2. MD2 pineapple fruits harvested from plant treated with (A) control plants; (B) chemical fertilizer; (C) vermicompost.

\subsection{Physicochemical Analysis of Fruits}

In comparison to the control, the TSS of the fruit juice from fruits harvested from pineapple plants treated with chemical fertilizer was lower $\left(9.93^{\circ}\right.$ Brix), followed by vermicompost $\left(9.32{ }^{\circ}\right.$ Brix) (Table 8$)$. The titratable acidity of the fruit juices ranged from $0.40 \mathrm{~g} \mathrm{~kg}^{-1}$ to $0.43 \mathrm{~g} \mathrm{~kg}^{-1}$, and was found to be not significantly different among all of the treatments.

Table 8. Physicochemical analysis of MD2 pineapple fruits grown with different types of fertilizers.

\begin{tabular}{cccc}
\hline Analysis & Control & Chemical Fertilizer & Vermicompost \\
\hline Total soluble solids $\left({ }^{\circ}\right.$ Brix $)$ & $11.13 \pm 0.31^{\mathrm{a}}$ & $9.93 \pm 0.48^{\mathrm{ab}}$ & $9.32 \pm 0.56^{\mathrm{b}}$ \\
Titratable acidity $\left(\mathrm{g} \mathrm{kg}^{-1}\right)$ & $0.40 \pm 0.04^{\mathrm{a}}$ & $0.43 \pm 0.04^{\mathrm{a}}$ & $0.43 \pm 0.02^{\mathrm{a}}$ \\
Sugar: acid ratio & 27.83 & 23.09 & 21.67 \\
\hline
\end{tabular}

Note: Mean \pm standard error of mean within each row followed by a different letter indicates significant differences at $p \leq 0.05$ according to Duncan's multiple range test (DMRT).

\subsection{Cost Analysis of Vermicompost Usage versus Chemical Fertilizer}

A cost analysis was also conducted to determine the effectiveness of using vermicompost as a replacement of chemical fertilizer in the field. Based on the results depicted in Table 9, the cost of organic supplement per plant per year (vermicompost) was 1.86 times higher than the cost of 
chemical fertilizer. However, due to vermicompost's characteristic as a slow release fertilizer, the labor cost (per plant per year) for the field maintenance for plants supplemented with vermicompost was 2.5 times lower (RM3.13) than that needed for plants supplemented with chemical fertilizer (RM7.81). In this study, the profit obtained from fruits produced by plants supplemented with vermicompost was slightly higher than that obtained using chemical fertilizer. However, the profit is estimated to significantly increase if the planting density of the seedlings is increased and if the field size is bigger.

Table 9. Cost analysis of MD2 pineapple fruits grown with vermicompost and chemical fertilizer.

\begin{tabular}{|c|c|c|c|}
\hline \multicolumn{2}{|c|}{ Cost Analysis } & \multirow{3}{*}{$\begin{array}{c}\text { Chemical Fertilizer } \\
\text { RM0.98 } \\
\text { RM2.42 } \\
\end{array}$} & \multirow{3}{*}{$\begin{array}{c}\text { Vermicompost } \\
\text { RM2.06 } \\
\text { RM4.50 }\end{array}$} \\
\hline \multirow{2}{*}{ Fertilizer } & Cost per $\mathrm{kg}$ fruit & & \\
\hline & Cost per plant per year & & \\
\hline \multirow{2}{*}{ Labor } & Cost per $\mathrm{kg}$ fruit & RM3.17 & RM1.43 \\
\hline & Cost per plant per year & RM7.81 & RM3.13 \\
\hline \multirow{2}{*}{ Total cost (labor + fertilizer) } & Cost per $\mathrm{kg}$ fruit & RM4.15 & RM3.49 \\
\hline & Cost per plant per year & RM10.23 & RM7.63 \\
\hline \multicolumn{2}{|c|}{ Market price of fruits } & \multicolumn{2}{|c|}{ RM8.00 per kg } \\
\hline \multirow{2}{*}{ Profit } & Profit per kg fruit & RM3.85 & RM4.51 \\
\hline & Profit per plant per year & RM9.50 & RM9.86 \\
\hline
\end{tabular}

Note: Labor cost $=$ RM50/day per person. Excludes costs of starting material (seedling), irrigation, and flower-inducing hormone.

\section{Discussion}

\subsection{Soil pH}

The current study found that the soil $\mathrm{pH}$ showed significant variation when different types of fertilizers were applied (Table 2). Surprisingly, the soil $\mathrm{pH}$ was found to increase when vermicompost was applied twice in one season. Similar results have been previously reported [26], where a significant increase of soil $\mathrm{pH}$ was observed after two consecutive applications of vermicompost (two years of transition) onto wheat plants grown on mildly acidic soils, compared to the application of NPK fertilizers. The $\mathrm{pH}$ of vermicompost-treated soils (at S1) fell below the control at the beginning due to the formation of organic acids through the degradation of organic compounds, which are easily mineralized later under aerobic conditions. This produces ammonium, which can subsequently increase the soil $\mathrm{pH}[39]$ and also reduce the potential of aluminum (Al) and manganese (Mn) toxicity [40].

In contrast, this study also found that the continuous application of chemical fertilizer decreased the soil $\mathrm{pH}$ over time. These results were in agreement with the findings from other studies that showed that the supplementation of NPK fertilizer also decreased the soil $\mathrm{pH}$ [41-43]. This might be due to the usage of chemical fertilizer that contained $9 \%$ ammonium $\left(\mathrm{NH}_{4}{ }^{+}\right)$and $6 \%$ nitrate $\left(\mathrm{NO}_{3}{ }^{-}\right)$ as the source of nitrogen to the soils. The acidifying effect of nitrification and leaching $\mathrm{of}^{\mathrm{NO}_{3}}{ }^{-}$ decreased the soil $\mathrm{pH}$ due to increasing the $\mathrm{H}^{+}$accumulation in the soils, caused by their release from $\mathrm{NH}_{4}{ }^{+}$[44].

In addition, these will also adversely affect the $\mathrm{pH}$ of poorly buffered soils, when a high rate of $\mathrm{N}$ is applied to sandy soils that are low in Ca. These were in agreement with the results obtained in this study, where the Ca content in the soils supplied with chemical fertilizer was found to be reduced by $56 \%$ during S2 (red bud stage), which in turn had resulted in a low soil pH (Table 3). This also justifies the increase of the $\mathrm{pH}$ of the soil added with vermicompost, as it contained twice the amount of Ca compared to soils supplied with chemical fertilizer (Table 3). These results are in accordance with the earlier reported findings Angelova, et al. [45], which showed that amendment with $10 \mathrm{~g} \mathrm{~kg}^{-1}$ of vermicompost resulted in an increase in soil $\mathrm{pH}$, with a high correlation coefficient between exchangeable $\mathrm{Ca}$ and soil $\mathrm{pH}(\mathrm{r}=0.90)$. 


\subsection{Macro and Micronutrients Content in the Soil and Pineapple Plant}

In this study, vermicompost was applied to the soil at the recommended dose of $10 \mathrm{t} \mathrm{ha}^{-1}$ [46]. In a study conducted on German chamomile (Matricaria chamomilla L.) grown under drought stress, M. chamomilla plants treated with $10 \mathrm{t} \mathrm{ha}^{-1}$ vermicompost were observed to exhibit normal nitrogen metabolism and photosynthesis, and produced less stressed-induced accumulation of proline than other plants [46]. Moreover, Zaman, et al. [47] reported that the application of vermicompost at $10 \mathrm{tha}^{-1}$ increased the fertility of acidic soil and non-calcareous soil grown with stevia, whereby both soil types showed significantly higher organic matter, total $\mathrm{N}$, available $\mathrm{P}$, exchangeable $\mathrm{K}, \mathrm{Ca}, \mathrm{Mg}$, available S, Zn, and B compared to when lower dosages of vermicompost were applied.

In this study, the application of vermicompost to the soils resulted in higher total $\mathrm{N}$ concentration in the soil and plant, compared to the control. However, the $\mathrm{N}$ concentration in the D-leaves was significantly lower compared to in the plants supplied with chemical fertilizer. This might be due to the humus content of the vermicompost, which resulted in a longer decomposing time and their characteristic as a slow-release fertilizer compared to chemical fertilizer, where $\mathrm{N}$ is in the form that is immediately available for plant uptake [3]. Other than that, the $\mathrm{P}, \mathrm{K}$, and Zn concentrations in the D-leaves of plants supplied with both vermicompost and chemical fertilizer were considered adequate for the crop.

On the other hand, the $\mathrm{Ca}$ and $\mathrm{Mg}$ concentrations in the D-leaves were reduced, possibly due to competition with $\mathrm{K}$ for nutrient uptake. There was a significant negative correlation between the $\mathrm{K}$ and Ca content in the D-leaves with a coefficient of $r^{2}=-0.682$ at $p<0.05$ (S1) and $r^{2}=-0.561$ (S2). Similar results were reported in the D-leaves of 'Smooth cayenne' pineapple, where the supplementation of a high amount of $\mathrm{K}$ correlated with the decrease of nutrient uptake of $\mathrm{Ca}$ and $\mathrm{Mg}$ [20]. In addition, unlike $\mathrm{Ca}^{2+}, \mathrm{Mg}^{2+}$ ions are more susceptible to leaching, since they are not as strongly adsorbed to clay minerals or organic matter due to their large hydrated radius [48].

At S2, the S, Fe, and B content in all of the samples were considered inadequate for plant growth, except the B concentration in the D-leaves of plants supplied with vermicompost $[16,37]$. In general, soils that are well provided with organic matter and with $\mathrm{pH}$ less than 7 will not usually face B deficiency $[19,49]$. However, the supplementation of higher doses of K-fertilizers may also affect $B$ availability in the soils [48]. In this study, a positive significant correlation was found between the $\mathrm{K}$ and $\mathrm{B}$ content in the soils with a coefficient of $\mathrm{r}^{2}=0.595$ at $p<0.05$. Moreover, the application of $\mathrm{S}$ fertilizers onto clay minerals at optimum doses does not have any residual effect, since clay minerals do not bind sulfate and thus, it is leached out of the soil [48].

\subsection{Morphophysiological Analysis of Pineapple Plants}

In pineapple plants, nitrogen $(\mathrm{N})$ is required second after potassium, especially during the vegetative stage to support plant growth and development [16]. In this study, the growth of pineapple plants supplemented with vermicompost was observed to be comparable to plants supplied with chemical fertilizer. The differences observed in the plant growth might be due to low $\mathrm{N}$ uptake by the plants. It has been previously reported that pineapple plants treated with $200 \mathrm{~kg} \mathrm{of} \mathrm{N} \mathrm{ha}^{-1}$ were $45 \%$ taller, showed increased D-leaf length, had 26\% more leaves and possessed a larger leaf area $\left(242.36 \mathrm{~cm}^{2}\right.$ ) than untreated (control) plants [25]. Moreover, the deficiency of N, K, Ca, and S concentrations in the leaves may lead to a reduction of the width of the D-leaves $[15,16,50]$. At S1, the concentration of $\mathrm{N}, \mathrm{K}$, and $\mathrm{Ca}$ in the control plants was lower than in plants supplemented with chemical fertilizer, as well as lower than the ideal concentration of nutrients required by the plants. As a result, the width of the D-leaves at six MAP and seven MAP were significantly different.

In order to avoid a deficiency or excess of $\mathrm{N}$ content in the leaves, a chlorophyll meter (SPAD-502), which is a non-destructive and rapid method, can be used to estimate the leaf chlorophyll and $\mathrm{N}$ content in situ. SPAD values lower than 40 indicated an impairment in the photosynthetic process [34]. Majic, et al. [51] reported that the SPAD values and the leaf $\mathrm{N}$ concentration showed a strong significant correlation ( $\mathrm{r}$ values ranged from $0.51^{* *}$ to $0.81^{* *}$ ) during the major physiological growth stages in a 
potato crop. Similar observation was found in this study, whereby data analysis revealed that there was a strong significant correlation between the SPAD values (10 MAP) and N levels in the leaves $\left(\mathrm{r}^{2}=0.877^{* *}, p<0.01\right)$ at S2. However, at S1 (six MAP), a weak correlation $\left(\mathrm{r}^{2}=0.428\right)$ was obtained. Based on Figure 2, the SPAD values of D-leaves from plants supplied with chemical fertilizer showed a steady increase from four MAP until the emergence of flowering (10 MAP). This might be because at the vegetative stage, chemical fertilizer and foliar sprays were periodically supplied to the soils and plants. For plants supplemented with vermicompost, the SPAD values were maintained from two MAP until six MAP. This could be due to the accumulated 'humus' in the compost, resulting in a constant release of 'organic nitrogen' and other nutrients [3].

\subsection{Physical Characteristics of Fruits}

With regard to the quality of the resulting fruits, the results of this study showed that the fruits produced from plants grown with chemical fertilizer were larger in size, followed by vermicompost and control, but fruits from plants supplemented with vermicompost had the smallest crown. Plants that are deficient in $\mathrm{N}$ will exhibit various physical symptoms such as producing smaller fruits with a small crown and the absence of plantlets [16]. Similar results were reported in a previous study on Jupi pineapple, where $\mathrm{N}$ deficiency had resulted in a $57.59 \%$ reduction of fruit weight (with crown); fruit length reduced by $38.7 \%$, and the fruit diameter reduced by $22 \%$ [52].

An important indicator of fruit freshness is their firmness, especially after storage. In this study, fruits produced from plants supplied with vermicompost were significantly firmer than fruits grown with chemical fertilizer. These results are in agreement with that reported in previous studies, where strawberries harvested from plants receiving vermicompost $\left(7 \mathrm{tha}{ }^{-1}\right)$ were significantly firmer than those harvested from plants receiving only inorganic fertilizer [12]. A possible explanation for this might be because of the excess of $\mathrm{N}$, which can contribute to a reduction in fruit pulp firmness [53]. In this study, the amount of nitrogen $(\mathrm{N})$ in plants treated with chemical fertilizer was found to be higher than in plants treated with vermicompost and control (unfertilized) during the red bud stages. Moreover, several reports have shown that calcium (Ca) is also responsible for the firmness of fruits such as in apple [54], peach [55], and blueberry [56]. Ca ions play a role in linking adjacent acidic pectin polymers in the cell walls, whereby during fruit ripening, major changes will occur in the pectin-rich middle lamella region of cells [57]. Reduced Ca levels in the cell walls would result in the structural failure of the tissues. However, in this study, no correlation was found between Ca content in the D-leaves and pulp firmness.

\subsection{Physicochemical Analysis of Pineapple Fruits}

The sugar-to-acid ratio is usually used as a measure of consumer taste preference. To obtain high-quality pineapple fruits, a sugar-to-acid ratio from 20 to 40 were recommended [58]. In this study, the sugar-to-acid ratio fell within the recommended range (21.67 to 27.80). The range of the TSS of fruits produced in this study was from 9.32 to $11.12^{\circ}$ Brix. The highest level in TSS content was obtained from fruits harvested from control (unfertilized) plants, which might be due to the low $\mathrm{N}$ content in the D-leaves. The total $\mathrm{N}$ in D-leaves showed a strong negative correlation with the TSS of fruit juice with a coefficient of $\mathrm{r}^{2}=-0.507$, indicating that the low $\mathrm{N}$ content resulted in the increase of the TSS of fruit juice. These results are in accordance with that reported by Darnaudery, Fournier and Lechaudel [23], whereby the highest level of TSS was observed in 'Queen Victoria' pineapple fruits, and was found to be caused by the decrease in N content in the D-leaves. Previous studies have also reported that fruit acidity tends to increase with increasing K content [59]. This is in agreement with the results of this study, where a significant increase in acidity was observed when the $\mathrm{K}$ content in the D-leaves was increased $\left(\mathrm{r}^{2}=0.712, p<0.05\right)$. In terms of fruit acidity, the application of vermicompost at $10 \mathrm{t} \mathrm{ha}^{-1}$ had been reported to result in lower fruit acidity in 'Chandler' strawberry compared to addition of inorganic nutrients [12]. However, pineapple fruits harvested from plants 
supplemented with vermicompost in this study were observed to have comparable fruit acidity levels with other treatments.

\subsection{Cost Analysis}

In this study, a rough cost analysis was conducted to determine the effectiveness of using vermicompost to replace chemical fertilizer in the field. It was observed that while the cost of vermicompost (per plant per year) was higher, the labor cost for field maintenance was significantly lower than that needed for plants supplemented with chemical fertilizer. This was due to its characteristic as a slow release fertilizer, which therefore does not require frequent incorporation into the soil. Based on these two criteria, the estimated profit obtained from fruits produced with vermicompost was observed to be slightly higher than that obtained using chemical fertilizer. However, the profit is estimated to significantly rise if the planting density of the seedlings and field size are increased. Also, other parameters of field maintenance such as the cost of irrigation and pest control could also play a major role in determining total profit (especially in big plantations). The cost of irrigation and pest control in vermicompost-treated areas are estimated to be significantly lower (data not shown) due to the excellent water-holding capacity of the vermicompost and its pest-repelling benefits $[1,60]$. Various studies have reported that vermicompost increases the 'biological resistance' in plants (due to Actinomycetes) and protect them against pest and diseases either by repelling or by suppressing them [61].

\section{Conclusions}

The preceding results showed that the utilization of vermicompost at the rate of $10 \mathrm{tha}^{-1}$ with two-split applications throughout the planting period produced comparable results (in terms of the growth of MD2 pineapple plants) with that obtained using conventional cultivation practices through regular supplementation with chemical fertilizer. In comparison to the control, the application of vermicompost produced fruits that were significantly larger in size with smaller crowns, but contained slightly lower TSS. The results of soil analysis showed that the application of vermicompost had significantly increased the soil $\mathrm{pH}$ and was able to retain the nutrients content in the soils. However, some of the nutrient uptake by the plants was lower than the concentration required for pineapple growth, similar to when chemical fertilizer was used. Thus, it could be deduced that both types of fertilizers (chemical fertilizer and vermicompost) could not supply the ideal concentration of nutrients required by pineapple plants, when they are used as the sole nutrient provider for plants grown on sandy soil. Therefore, further research needs to be carried out to identify the best ratio of the combination of vermicompost and chemical fertilizer to ensure agricultural sustainability and further reduce environmental pollution.

Author Contributions: R.A. and J.S.Y. conceived and designed the experiments; M.M. performed the experiments; M.M., R.A. and J.S.Y. analyzed the data; R.A. and J.S.Y contributed reagents/materials/analysis tools; M.M., R.A. and J.S.Y. wrote the paper.

Funding: This research was funded by University of Malaya [grant number RP015B-14AFR, PG016-2015B and CEBAR RU006-2017].

Acknowledgments: The authors thank the University of Malaya, Malaysia for experimental facilities and financial support [Grant No. RP015B-14AFR, PG016-2015B and CEBAR RU006-2017] provided.

Conflicts of Interest: The authors declare no conflict of interest.

\section{References}

1. Adhikary, S. Vermicompost, the story of organic gold: A review. Agric. Sci. 2012, 3, 905-917. [CrossRef]

2. Theunissen, J.; Nhakidemi, P.; Laublsher, C.P. Potential of vermicompost produced from plant waste on the growth and nutrient status in vegetable production. Int. J. Phys. Sci. 2010, 5, 1964-1973. 
3. Rajiv, K.S.; Sunita, A.; Krunal, C.; Dalsukh, V. The wonders of earthworms \& its vermicompost in farm production: Charles Darwin's 'friends of farmers', with potential to replace destructive chemical fertilizers from agriculture. Agric. Sci. 2010, 1, 76-94.

4. Azarmi, R.; Giglou, M.T.; Taleshmikail, R.D. Influence of vermicompost on soil chemical and physical properties in tomato (Lycopersicum esculentum) field. Afr. J. Biotechnol. 2008, 7, 2397-2401.

5. Roy, R.; Finck, A.; Blair, G.; Tandon, H. Plant Nutrition for Food Security: A Guide for Integrated Nutrient Management; FAO Fertilizer and Plant Nutrition Bulletin; FAO: Rome, Italy, 2006; Volume 16, p. 368.

6. Delgado, A.; Gómez, J.A. The soil. Physical, chemical and biological properties. In Principles of Agronomy for Sustainable Agriculture; Springer: Cham, Switzerland, 2016; pp. 15-26.

7. Baligar, V.; Fageria, N.; He, Z. Nutrient use efficiency in plants. Commun. Soil Sci. Plant Anal. 2001, 32, 921-950. [CrossRef]

8. Kmet'ová, M.; Kováčik, P. The impact of vermicompost application on the yield parameters of maize (Zea mays L.) observed in selected phenological growth stages (BBCH-scale). Acta Fytotech. Zootech. 2014, 17, 100-108. [CrossRef]

9. Yousefi, A.A.; Sadeghi, M. Effect of vermicompost and urea chemical fertilizers on yield and yield components of wheat (Triticum aestivum) in the field condition. Int. J. Agric. Crop. Sci. 2014, 7, 1227-1230.

10. Ayyobi, H.; Olfati, J.-A.; Peyvast, G.-A. The effects of cow manure vermicompost and municipal solid waste compost on peppermint (Mentha piperita L.) in torbat-e-jam and rasht regions of Iran. Int. J. Recycl. Org. Waste Agric. 2014, 3, 147-153. [CrossRef]

11. Zucco, M.A.; Walters, S.A.; Chong, S.-K.; Klubek, B.P.; Masabni, J.G. Effect of soil type and vermicompost applications on tomato growth. Int. J. Recycl. Org. Waste Agric. 2015, 4, 135-141. [CrossRef]

12. Singh, R.; Sharma, R.R.; Kumar, S.; Gupta, R.K.; Patil, R.T. Vermicompost substitution influences growth, physiological disorders, fruit yield and quality of strawberry (Fragaria x ananassa Duch.). Bioresour. Technol. 2008, 99, 8507-8511. [CrossRef] [PubMed]

13. Ghasem, S.; Morteza, A.S.; Maryam, T. Effect of organic fertilizers on cucumber (Cucumis sativus) yield. Int. J. Agric. Crop. Sci. 2014, 7, 808.

14. Banful, B.; Adjei, P.Y.; Idun, I.A. The influence of two pre and post-planting fungicides on the growth and fruiting of MD2 pineapple (Ananas comosus L. (merr)). Agric. Boil. J. N. Am. 2011, 2, 876-879. [CrossRef]

15. Malezieux, E.; Bartholomew, D.P. Plant nutrition. In The Pineapple: Botany Production, and Uses; Bartholomew, D.P., Paull, R.E., Rohrbach, K.G., Eds.; CAB International: Wallingford, UK, 2003; pp. 143-165.

16. Souza, L.F.d.S.; Reinhardt, D.H. Chapter 10: Pineapple. In Fertilizing for High Yield and Quality: Tropical Fruit of Brazil; IPI Bulletin No.18 ed.; Crisóstomo, L.A., Naumov, A., Eds.; International Potash Institute: Horgen, Switzerland, 2007; pp. 179-201.

17. Aiyelaagbe, I.O.O.; Oshuniyi, A.A.; Adegoke, J.O. Respone of 'Smooth Cayenne' Pineapple to Organic Fertilizer in South Western Nigeria; International Society for Horticultural Science (ISHS): Leuven, Belgium, 2012; pp. 261-264.

18. Liu, C.H.; Liu, Y.; Fan, C.; Kuang, S.Z. The effects of composted pineapple residue return on soil properties and the growth and yield of pineapple. J. Soil Sci. Plant Nutr. 2013, 13, 433-444. [CrossRef]

19. Maeda, A.S.; Buzetti, S.; Boliani, A.C.; Benett, C.G.S.; Filho, M.C.M.T.; Andreotti, M. Foliar fertilization on pineapple quality and yield. Pesqui. Agropecuária Trop. 2011, 41, 248-253.

20. Teixeira, L.A.J.; Quaggio, J.A.; Cantarella, H.; Mellis, E.V. Potassium fertilization for pineapple: Effects on soil chemical properties and plant nutrition. Rev. Bras. Frutic. 2011, 33, 627-636. [CrossRef]

21. Arshad, A.M.; Armanto, M.E. Effect of nitrogen on growth and yield of pineapple grown on bris soil. J. Environ. Sci. Eng. B 2012, 1, 1285-1289.

22. Orluchukwu, J.A.; Adedokun, O.M. Response of growth and yield of pineapple (Ananas comosus) on spent mushroom substrates and inorganic fertilizer in south-south, Nigeria. Int. J. Plant Soil Sci. 2015, 8, 1-5. [CrossRef]

23. Darnaudery, M.; Fournier, P.; Lechaudel, M. Low-input pineapple crops with high quality fruit: Promising impacts of locally integrated and organic fertilisation compared to chemical fertilisers. Exp. Agric. 2016, 54, 286-302. [CrossRef]

24. MPIB, M.P.I.B. Pengurusan Tanaman Nanas Pelbagai Kultivar. 2018. 18. Available online: http://www. youblisher.com/p/44324-Pengurusan-Tanaman-Nanas-Pelbagai-Kultivar/ (accessed on 19 August 2018). 
25. Omotoso, S.O.; Akinrinde, E.A. Effect of nitrogen fertilizer on some growth, yield and fruit quality parameters in pineapple (Ananas comosus L. Merr.) plant at ado-ekiti southwestern, Nigeria. Int. Res. J. Agric. Sci. Soil Sci. 2013, 3, 11-16.

26. Gopinath, K.A.; Saha, S.; Mina, B.L.; Pande, H.; Kundu, S.; Gupta, H.S. Influence of organic amendments on growth, yield and quality of wheat and on soil properties during transition to organic production. Nutr. Cycl. Agroecosyst. 2008, 82, 51-60. [CrossRef]

27. Hotegni, F.; Nicodème, V.; Lommen, W.J.; Agbossou, E.K.; Struik, P.C. Heterogeneity in pineapple fruit quality results from plant heterogeneity at flower induction. Front. Plant Sci. 2014, 5, 670.

28. Shariff, A.H.M.; Miller, H.G. Site fertility and its influence on the stocking of dipterocarp species in the tropical rain forest of peninsular Malaysia. J. Trop. For. Sci. 1989, 4, 189-201.

29. LECO. Nitrogen Analyzer fp-528 Instruction Manual; LECO Corporation: St. Joseph, MI, USA, 2001.

30. Bremmer, J.M.; Mulvaney, C.S. Nutrient total. In Methods of Soil Analysis; ASA: Mediason, WI, USA, 1982; pp. 595-624.

31. Chen, M.; Ma, L.Q. Comparison of three aqua regia digestion methods for twenty florida soils approved for publication as florida agricultural experiment station journal series no. R-06802. Soil Sci. Soc. Am. J. 2001, 65, 491-499. [CrossRef]

32. Yeoh, H.F. Working Manual for Plant Analysis and Analytical Services Branch; Department of Agriculture: Kuala Lumpur, Malaysia, 1975.

33. Isaac, R.A.; Johnson, W.C.; Kalra, Y. Elemental determination by inductively couple plasma atomic emmision spectrometry. In Handbook of Reference Methods for Plant Analysis; Kalra, Y.P., Ed.; CRC Press LLC: Boca Raton, FL, USA, 1988; pp. 165-170.

34. Netto, A.T.; Campostrini, E.; Oliveira, J.G.A.D.; Bressan-Smith, R.E. Photosynthetic pigments, nitrogen, chlorophyll a fluorescence and SPAD-502 readings in coffee leaves. Sci. Hortic. 2005, 104, 199-209. [CrossRef]

35. Appiah, F.; Kumah, P.; Oppong, D. Predicting the consumer accepatability of dried MD2 and Smooth cayenne pineapple pulps from chemical composition. J. Food Res. 2012, 1, 210-216. [CrossRef]

36. Times, T.S. Malaysian Pineapples in Demand in China. 2017, 1. Available online: https://www.straitstimes. com/asia/se-asia/malaysian-pineapples-in-demand-in-china (accessed on 19 August 2018).

37. Ramos, M.J.M.; Monnerat, P.H.; da R. Pinho, L.G.; de A. Pinto, J.L. Growth and Flowering of 'Imperial' Pineapple Plants under Macronutrient and Boron Deficiency 2009; International Society for Horticultural Science (ISHS): Leuven, Belgium, 2009; pp. 139-146.

38. Thalip, A.A.; Tong, P.S.; Ng, C. The MD22 ' sweet' pineapple (Ananas comosus). UTAR Agric. Sci. J. 2015, 1, 14-17.

39. Beck-Friis, B.; Smårs, S.; Jönsson, H.; Eklind, Y.; Kirchmann, H. Composting of source-separated household organics at different oxygen levels: Gaining an understanding of the emission dynamics. Compos. Sci Util. 2003, 11, 41-50. [CrossRef]

40. Nada, W.M.; van Rensburg, L.; Claassens, S.; Blumenstein, O. Effect of vermicompost on soil and plant properties of coal spoil in the lusatian region (eastern Germany). Commun. Soil Sci. Plant Anal. 2011, 42, 1945-1957. [CrossRef]

41. Han, S.H.; An, J.Y.; Hwang, J.; Kim, S.B.; Park, B.B. The effects of organic manure and chemical fertilizer on the growth and nutrient concentrations of yellow poplar (Liriodendron tulipifera Lin.) in a nursery system. For. Sci. Technol. 2016, 12, 137-143.

42. Milosevic, T.; Milosevic, N. The effect of zeolite, organic and inorganic fertilizers on soil chemical properties, growth and biomass yield of apple trees. Plant Soil Environ. 2009, 55, 528-535. [CrossRef]

43. Brar, B.S.; Singh, J.; Singh, G.; Kaur, G. Effects of long term application of inorganic and organic fertilizers on soil organic carbon and physical properties in maize-wheat rotation. Agronomy 2015, 5, 220-238. [CrossRef]

44. Bolan, N.S.; Hedley, M.J. Role of carbon, nitrogen, and sulfur cycles in soil acidification. In Handbook of Soil Acidity; Rengel, Z., Ed.; Marcel Dekker: New York, NY, USA, 2003; pp. $29-56$.

45. Angelova, V.R.; Akova, V.I.; Artinova, N.S.; Ivanov, K.I. The effect of organic amendments on soil chemical characteristics. Bulg. J. Agric. Sci. 2013, 19, 958-971.

46. Salehi, A.; Tasdighi, H.; Gholamhoseini, M. Evaluation of proline, chlorophyll, soluble sugar content and uptake of nutrients in the German chamomile (Matricaria chamomilla L.) under drought stress and organic fertilizer treatments. Asian Pac. J. Trop. Biomed. 2016, 6, 886-891. [CrossRef] 
47. Zaman, M.M.; Chowdhury, M.A.H.; Islam, M.R.; Uddin, M.R. Effects of vermicompost on growth and leaf biomass yield of stevia and post harvest fertility status of soil. J. Bangladesh Agric. Univ. 2015, 12, 169-174. [CrossRef]

48. Mitra, G. Essential plant nutrients and recent concepts about their uptake. In Essential Plant Nutrients: Uptake, Use Efficiency, and Management; Naeem, M., Ansari, A.A., Gill, S.S., Eds.; Springer: Cham, Switzerland, 2017; pp. 3-35.

49. Basso, C.; Suzuki, A. Solos e nutrição. In Nashi: A Pêra-Japonesa; Epagri/JICA: Florianópolis, Brazil, 2001; pp. 139-160.

50. De Jesus Matos Viegas, I.; de Nazare Paes da Silva, R.; Seabra Silva, D.A.; de Oliveira Neto, C.F.; da Conceicao, H.E.O.; da Silva Mascarenhas, G.; Okumura, R.S.; Monfort, L.E.F.; da Silva, R.T.T.L. Mineral composition and visual symptoms of nutrients deficiencies in curauá plants (Ananas comosus var. Erectifolius). Aust. J. Crop. Sci. 2014, 8, 747-753.

51. Majic, A.; Poljak, M.; Sabljo, A.; Knezovic, Z.; Horvat, T. Effeciency of use of chlorophyll meter and cardy-ion meter in potato nitrogen nutrition supply. Cereal Res. Commun. 2008, 36, 1431-1434.

52. Ramos, M.J.M.; da Rocha Pinho, L.G. Physical and quality characteristics of Jupi pineapple fruits on macronutrient and boron deficiency. Nat. Resour. 2014, 5, 359-366. [CrossRef]

53. Py, C.; Lacoueilhe, J.J.; Teison, C. The Pineapple, Cultivation and Uses; G. P. Maisonneuve et Larose: Paris, France, 1987.

54. Beavers, W.B.; Sams, C.E.; Conway, W.S.; Brown, G.A. Calcium source affects calcium content, firmness, and degree of injury of apples during storage. HortScience 1994, 29, 1520-1523.

55. Gupta, N.; Jawandha, S.K.; Gill, P.S. Effect of calcium on cold storage and post-storage quality of peach. J. Food Sci. Technol. 2011, 48, 225-229. [CrossRef] [PubMed]

56. Ochmian, I. The impact of foliar application of calcium fertilizers on the quality of highbush blueberry fruits belonging to the 'Duke' cultivar. Not. Bot. Horti Agrobot. 2012, 40, 163-169. [CrossRef]

57. Tucker, G.A. Introduction. In Biochemistry of Fruit Ripening; Seymour, G.B., Taylor, J.E., Tucker, G.A., Eds.; Chapman \& Hall: London, UK, 1993.

58. Soler, A. Pineapple; CIRAD-IRFA: Paris, France, 1992.

59. Razzaque, A.H.M.; Hanafi, M.M. Effect of potassium on growth, yield and quality of pineapple in tropical peat. Fruits 2001, 56, 45-49. [CrossRef]

60. Arancon, N.Q.; Edwards, C.A. Effects of Vermicomposts on Plant Growth; Soil Ecology Laboratory, The Ohio State University: Columbus, OH, USA, 2005; Volume 43210, pp. 16-18.

61. Sinha, R.K. Earthworms: The miracle of nature (Charles Darwin's 'unheralded soldiers of mankind \& farmer's friends'). Environmentalist 2009, 29, 339-340. 